\title{
Study of Various Prognostic Factors in Prostate Cancer and its Correlation with Androgen Receptor Expression
}

\author{
Lekshmy K. S. ${ }^{1}$, Prema N. S. ${ }^{2}$ \\ ${ }^{1}$ Senior Resident, Department of Pathology, Government Medical College, Kollam, Kerala, India. \\ ${ }^{2}$ Associate Professor, Department of Pathology, Government Medical College, Kollam, Kerala, India.
}

\section{ABSTRACT}

\section{BACKGROUND}

Prostate cancer is the fourth most common cancer in the world. The number of cases reported has been continuously increasing over the past decade partly due to higher life expectancy and also due to western lifestyle characterized by high caloric diet and lack of physical exercise. Prostate cancer varies substantially in aggressiveness. Morphologic feature-based and molecular-based prognostic factors can play an important role in distinguishing the indolent cases from the invasive tumours capable of distant metastasis and producing androgen independent fatal disease. This study is an attempt to evaluate some of the prognostic factors including Androgen Receptor (AR) expression in carcinoma prostate. Correlation of AR expression with the various prognostic factors is also done. This may give a clue in predicting the more aggressive behaviour of some of the cases.

\section{METHODS}

82 cases of carcinoma prostate diagnosed during a two-year period were included in the study. Age, pre-treatment PSA levels, clinical stage and per-rectal $(P / R)$ examination findings were collected from case records. From all specimens, haematoxylin and eosin stained sections were prepared and morphological factors were studied. All cases were subjected to immunohistochemical staining for AR expression.

\section{RESULTS}

A significant negative correlation (Spearman's rank order correlation coefficient $\left(r_{s}\right)=-0.400$, Significance $(p)=0.001$ ) was obtained between Androgen Receptor expression and Gleason score. A weak, negative significant correlation $\left(r_{s}=-0.326\right.$, $\mathrm{p}=0.009$ ) was obtained between Androgen Receptor expression and percentage of involved cores. Age, PSA levels and perineural invasion did not show significant correlation with Androgen Receptor expression.

\section{CONCLUSIONS}

This study focused on evaluating the relationship of Androgen Receptor expression with various prognostic factors associated with carcinoma prostate. It was found that AR expression has a negative relationship with Gleason score and percentage of involved cores. But other prognostic factors did not show significant correlation. Further studies with higher sample size and correlation with survival analysis are indicated in this regard.

\section{KEY WORDS}

Carcinoma Prostate, Androgen Receptor, Prognosis, Gleason Score
Corresponding Author:

Dr. Prema N. S., TC 29/1125, Chandni, Devi Nagar, Palkulangara, Trivandrum-695024, Kerala, India.

E-mail: premansdr@gmail.com

DOI: $10.14260 / \mathrm{jemds} / 2019 / 584$

Financial or Other Competing Interests: None.

How to Cite This Article:

Lekshmy KS, Prema NS. Study of various prognostic factors in prostate cancer and its correlation with androgen receptor expression. J. Evolution Med. Dent. Sci. 2019;8(34):2687-2693, $10.14260 /$ jemds $/ 2019 / 584$

Submission 29-06-2019,

Peer Review 09-08-2019,

Acceptance 16-08-2019,

Published 26-08-2019. 


\section{BACKGROUND}

Prostate cancer is the fourth most common cancer in the world. [1] It contributes significantly to overall cancer burden, being the second most common malignant neoplasm in males. [1] The number of cases reported has been continuously increasing over the past decade partly due to higher life expectancy, due to western life-style characterized by high caloric diet, lack of physical exercise and the use of serum prostate-specific antigen (PSA) screening for the detection of prostate cancer. [2] Prostate cancer varies substantially in aggressiveness. Morphologic feature-based and molecularbased prognostic factors can play an important role in distinguishing the indolent cases from the invasive tumours capable of distant metastasis and producing androgen independent, antiandrogen-resistant fatal disease $[3,4,5,6]$ The College of American Pathologists (CAP) has classified prognostic factors into three categories. ${ }^{4]}$ Some of the factors in these categories are TNM stage, Gleason score, preoperative serum PSA, histologic type, tumour amount in needle biopsy tissue and radical prostatectomy specimen etc. These factors can play an important role in determining the natural history of carcinoma prostate, modality of treatment and predicting the risk of recurrence after treatment. Androgens play a fundamental role in the growth, differentiation and maintenance of prostate tissue and their effects are mediated via a specific Androgen Receptor (AR). Huggins et al found out in their study that castration induces prostate tumour regression. [7] The first line therapy for metastatic prostate cancer are based on methods designed to prevent androgenic stimulation of the tumour. The AR molecule is a major part of the regulatory androgen-AR complex and is therefore critical in the androgen-AR pathway of carcinoma prostate [7, 8, 9] Thus AR expression represents a potential marker of prognosis and hormonal responsiveness in carcinoma prostate. Many studies have been done in this field. But the results regarding the number of cells expressing $\mathrm{AR}$ in cancer and the ability to predict clinical progression and survival are variable. [10,11,12,13]

This study is an attempt to evaluate some of the prognostic factors including Androgen Receptor expression in carcinoma prostate. Correlation of AR expression with the various prognostic factors is also done. This may give a clue in predicting the more aggressive behaviour of some of the cases.

\section{METHODS}

This is a descriptive study of 82 cases of carcinoma prostate received in department of Pathology Government Medical College Trivandrum during a time period of two years. Human Ethics Committee clearance was obtained before starting the study. All prostate core biopsy, prostatectomy and Transurethral Resection of Prostate (TURP) specimens with histologically proven carcinoma prostate were included in the study Age, pre-treatment PSA levels, clinical stage and Per-rectal (P/R) examination findings were collected from case records. All specimens were fixed in $10 \%$ neutral buffered formalin. Gross features like number of cores in case of prostate core biopsy, tumour size and extent in case of prostatectomy were assessed. Entire tissue was processed in core biopsies. Bits were taken from all representative areas in case of prostatectomy specimen. While embedding core biopsy, care was taken so that not more than two cores were embedded in the same block. Paraffin embedded haematoxylin and eosin stained sections were prepared. In all cases various morphological prognostic factors were studied.

The following morphological factors were studied-

- Histological grade by Gleason score

- Histologic subtype of carcinoma.

- Presence of perineural invasion.

- Volume of cancer in needle core biopsy (Number of cores involved and percentage of involvement) and prostatectomy specimen.

- Surgical margins in prostatectomy specimen.

All cases were subjected to immunohistochemical staining for Androgen receptor. The number and intensity of immuno reactive nuclei were assessed. Because of the heterogeneous content of positive staining cells in the tumours, slides were scanned at $40 \mathrm{x}$ to find the areas of highest staining and 1,000 epithelial cells within a hot spot were counted. The number of positive nuclei is expressed as a percentage of the total number counted. Intensity of staining was evaluated subjectively on a scale of $0-3$, where $0=$ no staining, $1=$ weak equivocal staining, $2=$ unequivocal moderate staining and $3=$ strong staining. Then histological score (HSCORE), which is a measure of both intensity and distribution of staining, was calculated using the following equation:

\section{$\operatorname{HSCORE}=\sum \mathrm{Pi}(\mathrm{i}+1)^{[8]}$}

Where,

Pi: percentage of stained epithelial cells for each intensity. i: intensity of staining.

Statistical calculations were performed using Statistical Package for Social Sciences (SPSS) software. Assessment of normality of data using Kolmogorov-Smirnov test and Shapiro-Wilk test was done, and it was found that data was not normally distributed so correlation of HSCORE with various prognostic factors was done using Spearman's rank order correlation and Pearson's Chi-Square tests.

\section{RESULTS}

In the present study mean age was 70 years, the mean PSA level was $77.7 \mathrm{ng} / \mathrm{dl}$, the mean Gleason score was 8 . Half of the cases $(50 \%)$ were poorly differentiated carcinoma with Gleason score 8-10 followed by moderately differentiated carcinoma (Figure 7, Figure 8, Figure 9, Figure 10). Most common histological subtype was usual type adeno carcinoma. Of the 63 core biopsies studied 48 cases showed involvement of more than half of the number of cores This could not be assessed in 19 cases because they were either TURP or prostatectomy specimens. Perineural invasion was present in $43 \%$ of cases (Figure 11). 
It was observed that AR immunoreactivity was almost exclusively nuclear and was seen in the tumour cells and focally in the non-neoplastic glandular epithelial cells (Figure 2). AR positive cells are heterogeneously distributed in the tumour. It was found that intensity of staining and distribution of stained cells varied from one spot to another with in the same tumour (Figure 1). It was also observed that stained cells were significantly higher in tumour than in normal prostate tissue. HSCORE was calculated in all the cases depending on intensity of staining and number of nuclei stained (Figure 3, Figure 4, Figure 5, Figure 6). In the present study, HSCORE ranges from 0-290. Mean HSCORE was 145

As part of statistical analysis, normality of the data (prognostic factors) was assessed and it was observed that these were not normally distributed. Accordingly, as per standard procedure, non-parametric tests were conducted to determine the relationship between Androgen Receptor expression and various prognostic factors. All the prognostic factors excluding perineural invasion are quantitative variables. Hence, Spearman's Rank order correlation coefficient was used to measure the strength and direction of association of these variables with Androgen Receptor expression. Since perineural invasion is a categorical variable (Absent/present), Pearson's Chi-Square test was carried out to determine existence of relationship with HSCORE

A moderate, negative monotonic, significant correlation ( $\mathrm{rs}=-0.400, \mathrm{p}=0.001$ ) was obtained between Androgen Receptor expression and Gleason score. A weak, negative monotonic, significant correlation ( $r s=-0.326, p=0.009$ was obtained between Androgen Receptor expression and percentage of involved cores (Table 1). Age, PSA levels and perineural invasion did not show significant correlation with Androgen Receptor expression (Table 1, Table 2)

\begin{tabular}{|c|c|c|c|}
\hline \multirow{2}{*}{$\begin{array}{c}\text { Prognostic } \\
\text { Factors }\end{array}$} & Frequency & $\begin{array}{c}\text { Spearman's Rank Order } \\
\text { Correlation Coefficient (rs) }\end{array}$ & $\begin{array}{c}\text { Significance } \\
\text { (p) }\end{array}$ \\
\cline { 2 - 4 } & 82 & -0.400 & 0.001 \\
\hline Gleason Score & 82 & -0.050 & 0.653 \\
\hline Age & 82 & -0.133 & 0.287 \\
\hline PSA levels & -0.326 & 0.009 \\
\hline $\begin{array}{c}\text { Percentage of } \\
\text { involved cores }\end{array}$ & 63 & \multicolumn{3}{|c|}{ Prognostic Factors } \\
\hline \multicolumn{4}{|c|}{ Table 1. Correlation between Androgen Receptor Expression \& } \\
\hline
\end{tabular}

\begin{tabular}{|c|c|c|c|c|}
\hline $\begin{array}{c}\text { Perineural } \\
\text { Invasion }\end{array}$ & $\begin{array}{c}\text { HSCORE } \\
\text { (Frequency) }\end{array}$ & $\begin{array}{c}\text { Pearson's } \\
\text { Chi-Square }\end{array}$ & $\begin{array}{c}\text { Degrees of } \\
\text { Freedom (df) }\end{array}$ & $\begin{array}{c}\text { Significance } \\
\text { (p) }\end{array}$ \\
\cline { 1 - 2 } Present & 35 & 33.767 & 34 & 0.479 \\
\hline Absent & 47 & & & \\
\cline { 1 - 3 } Table 2. Pearson's Chi-Square Test between Androgen Receptor \\
Expression (HSCORE) \& Perineural Invasion \\
\hline
\end{tabular}

\begin{tabular}{|c|c|}
\hline Study & Mean Age (Years) \\
\hline Qiu YQ et al $\left[{ }^{10]}\right.$ & 64.9 \\
\hline Husain I et al ${ }^{[14]}$ & 64.7 \\
\hline Tyagi et al[ ${ }^{[23]}$ & 69.7 \\
\hline Tindall E et al ${ }^{[24]}$ & 71.0 \\
\hline Present Study & 70.0 \\
\hline \multicolumn{2}{|c|}{ Table 3. Age Comparison } \\
\hline
\end{tabular}

\begin{tabular}{|c|c|c|}
\hline Serum PSA Level & Frequency & Percent \\
\hline$<4$ & 2 & 2.4 \\
\hline 4 to 10 & 12 & 14.6 \\
\hline 11 to 20 & 13 & 15.9 \\
\hline Above 20 & 55 & 67.1 \\
\hline Total & $\mathbf{8 2}$ & $\mathbf{1 0 0 . 0}$ \\
\hline \multicolumn{2}{|c|}{ Table 4. Serum PSA Level } \\
\hline
\end{tabular}

\begin{tabular}{|c|c|c|c|c|}
\hline Study & \multicolumn{2}{|c|}{$\begin{array}{c}\text { Well } \\
\text { Differentiated } \\
\text { (Up To 6) }\end{array}$} & $\begin{array}{c}\text { Moderately } \\
\text { Differentiated } \\
\text { (7) }\end{array}$ & $\begin{array}{c}\text { Poorly } \\
\text { Differentiated } \\
(8-10) \\
\end{array}$ \\
\hline Qiu YQ et al ${ }^{[10]}$ & \multicolumn{2}{|c|}{$50 \%$} & $31 \%$ & $19 \%$ \\
\hline Spalding AC et al[17] & \multicolumn{2}{|c|}{$43 \%$} & $42 \%$ & $15 \%$ \\
\hline Tindall E et al[16] & \multicolumn{2}{|c|}{$23.4 \%$} & $50.7 \%$ & $25.9 \%$ \\
\hline Present study & \multicolumn{2}{|c|}{$15.9 \%$} & $34.1 \%$ & $50.0 \%$ \\
\hline \multicolumn{5}{|c|}{ Table 5. Comparison of Gleason Score in Various Studies } \\
\hline \multirow{2}{*}{\multicolumn{2}{|c|}{ Study }} & \multicolumn{3}{|c|}{ Percentage of Involved Cores } \\
\hline & & \multicolumn{2}{|r|}{\begin{tabular}{l|l}
$\leq 50 \%$ & \\
\end{tabular}} & $>50 \%$ \\
\hline \multicolumn{2}{|c|}{ Spalding AC et al [17] } & & $47 \%$ \\
\hline \multicolumn{2}{|c|}{ Freedland SJ et al [18] } & \multicolumn{2}{|r|}{$52 \%$} & $48 \%$ \\
\hline Present Stuc & & & $24 \%$ & $76 \%$ \\
\hline \multicolumn{5}{|c|}{$\begin{array}{c}\text { Table 6. Comparison of Percentage of Involved Cores in } \\
\text { Various Studies }\end{array}$} \\
\hline \multirow{2}{*}{\multicolumn{2}{|c|}{ Study }} & & \multicolumn{2}{|c|}{ Perineural Invasion } \\
\hline & & & Present & Absent \\
\hline \multicolumn{2}{|c|}{ William W Wong et al[19] } & & $9 \%$ & $91 \%$ \\
\hline \multicolumn{2}{|c|}{ Sara 0 Vargas et al[20] } & & $16.8 \%$ & $83.2 \%$ \\
\hline \multicolumn{2}{|c|}{ de la Taille A et al[21] } & & $24 \%$ & $76 \%$ \\
\hline \multicolumn{2}{|c|}{ D'Amico AV et al[22] } & & $7 \%$ & $93 \%$ \\
\hline \multicolumn{2}{|c|}{ Present study } & & $42.7 \%$ & $57.3 \%$ \\
\hline \multicolumn{5}{|c|}{ Table 7. Comparison of Perineural Invasion } \\
\hline
\end{tabular}
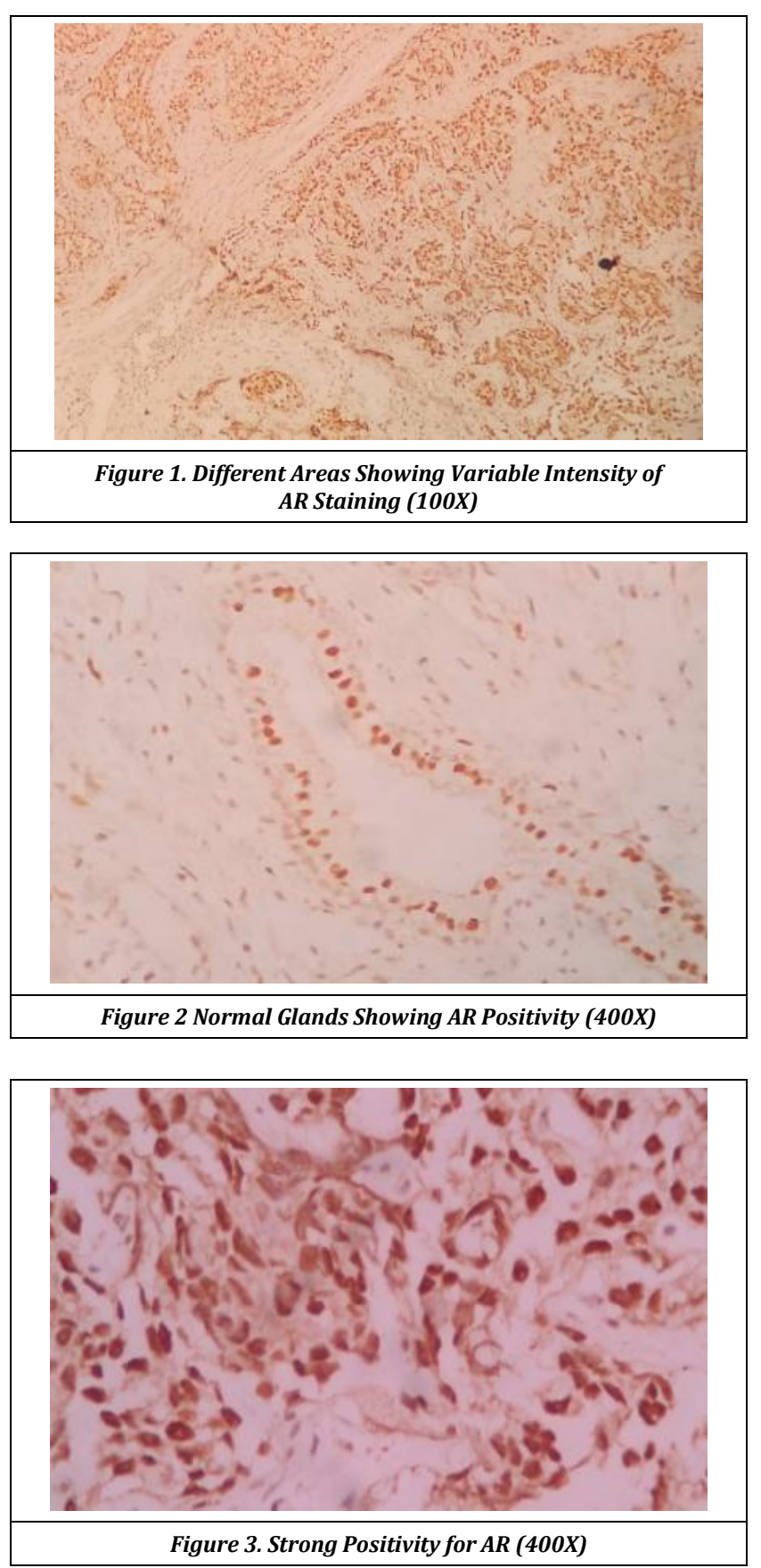


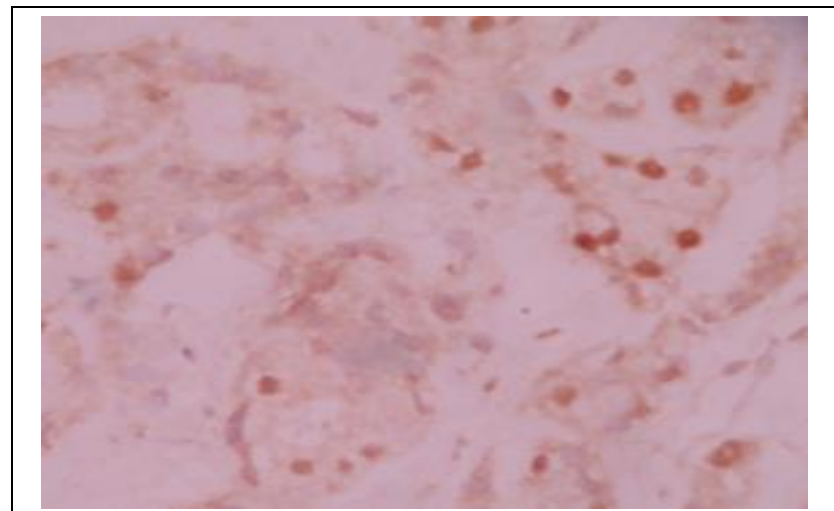

Figure 4. Weak Positivity for AR (400X)
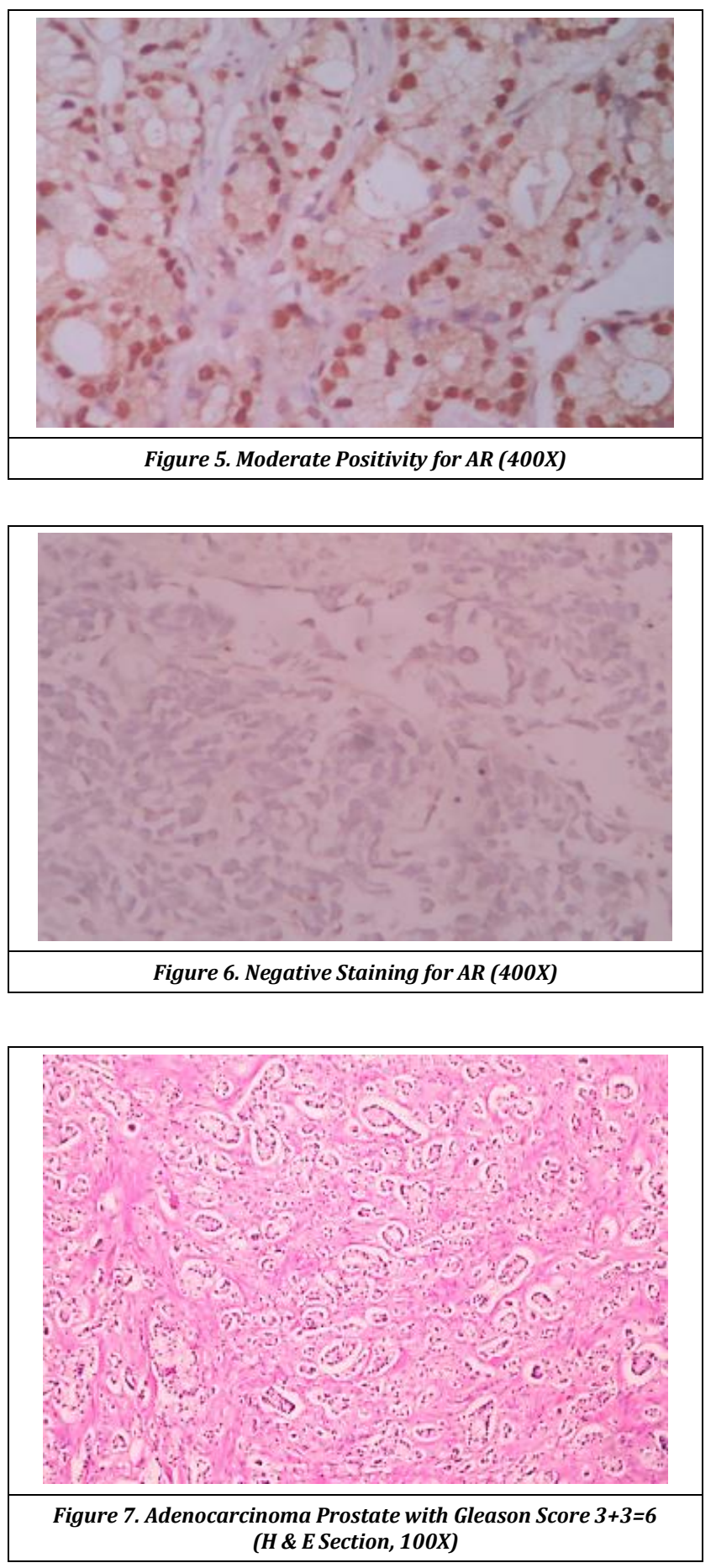

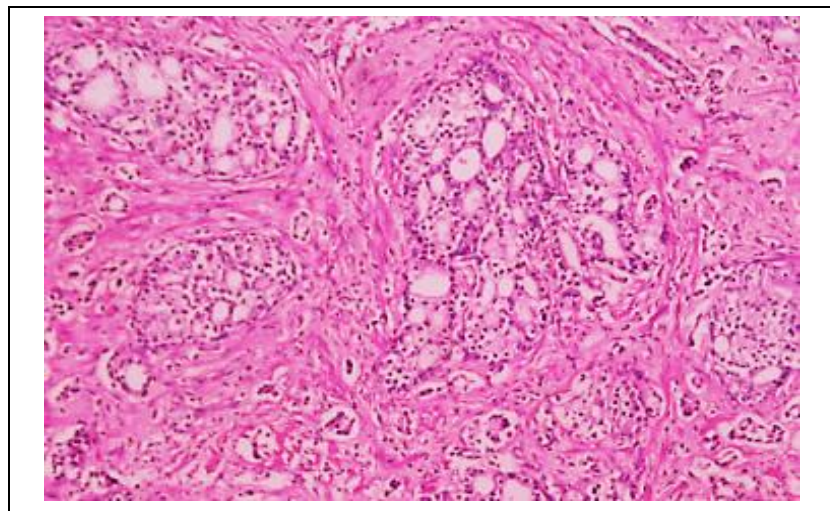

Figure 8. Adenocarcinoma Prostate Showing Cribriform Pattern (H \& E Section, 100X)

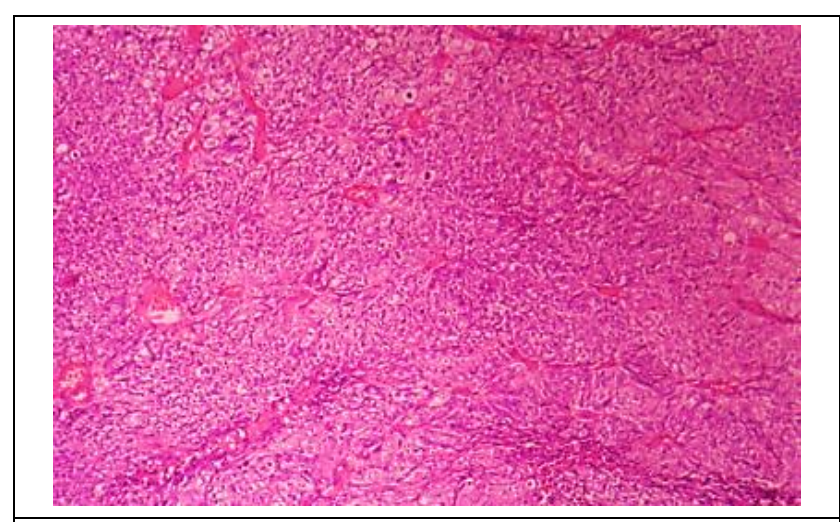

Figure 9. Adenocarcinoma Prostate Showing Sheet like Pattern (H \& E Section, 100X)
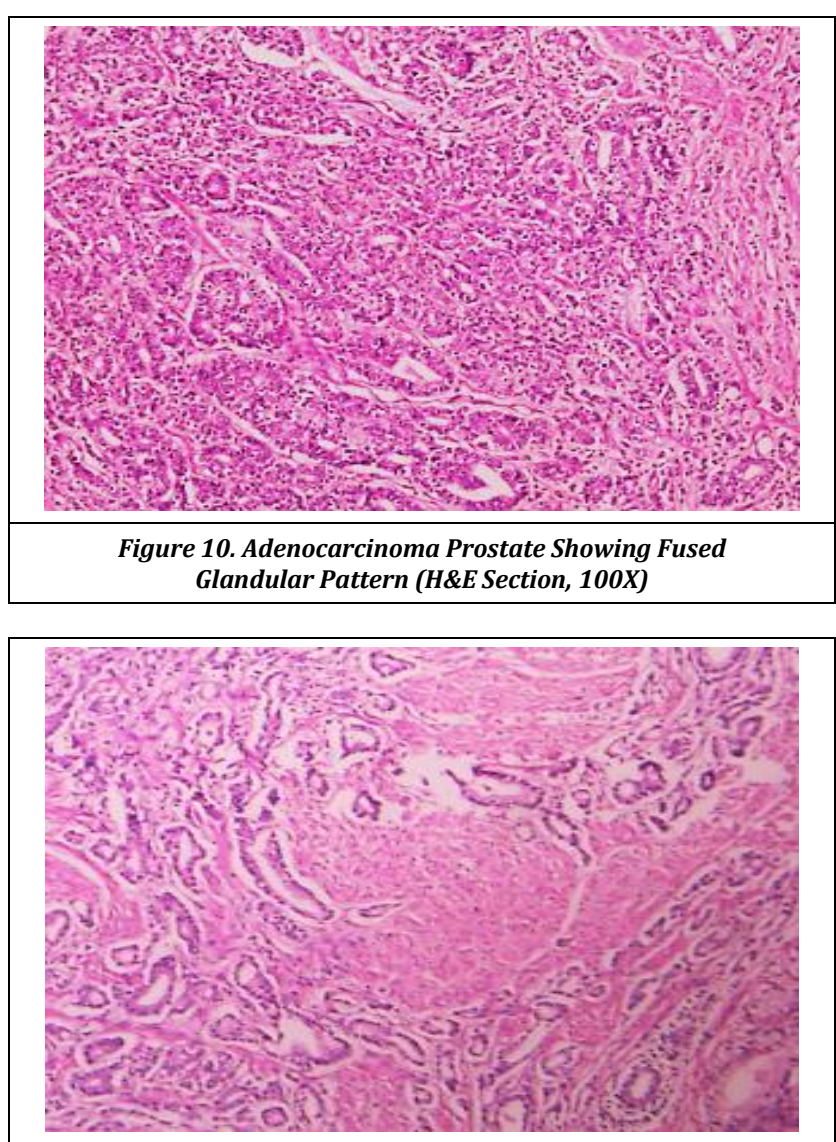

Figure 11. Adenocarcinoma Prostate Showing Perineural Invasion (H \& E Section, 100X) 


\section{DISCUSSION}

Prostate cancer is the fourth most common cancer in the world. Prognostic factors can play an important role in determining natural history of carcinoma prostate, modality of treatment and predicting the risk of recurrence after treatment. Most of the cases are diagnosed at an early stage due to increased use of serum PSA as a screening test. But there are no molecular markers available that segregate clinically indolent cases from aggressive ones. A better understanding of the biologic mechanism and the role played by $\mathrm{AR}$ receptors in carcinoma prostate allow improved clinical management and provide new targets for therapy. The mean age of the patients in present study was 70 yrs. This was almost similar to most of the previous studies as shown in (Table 3). A vast majority of the patients in this study had a PSA level above $20 \mathrm{ng} / \mathrm{dl}$ and the mean PSA value was $77 \mathrm{ng} / \mathrm{dl}$ (Table 4). 59.8\% study population had Stage I disease. Study conducted by Niroomand $\mathrm{H}$ et al[14] also showed similar results. According to Qiu YQ et al [10] and Husain I et al [23] Stage II is most common. This difference may be due to difference in sample size and difference in study population. All the 82 cases were usual type adenocarcinoma. This was almost similar to studies by Humphrey PA[24] Mazzucchelli R et al[25] Randolph et al[26] and Grignon DJ[27] etc.

$50 \%$ of the cases in present study were poorly differentiated carcinoma with Gleason score 8-10. This is in contrast to observation made in most of the previous studies. This could possibly be explained to some extent by the subjective nature of assessment involved (Table 5)_of the 63 prostate biopsies studied, 48 showed involvement of more than half of the number of cores. This is in contrast to most of the previous studies (Table 6). This may be due to difference in the number of cores studied in each case, in various studies. Most of the studies in literature are based on sextant biopsies. But in this study, most of the cases were nodule directed biopsies or targeted biopsies and number of cores sampled is less. This may be the reason for the variations in the results obtained._Perineural invasion was present in 42.7 $\%$ of the cases. This was more when compared with most of the previous studies (Table 7). This could possibly be explained to some extent by the subjective nature of assessment involved.

With regard to Androgen Receptor expression it was found that all except three cases showed nuclear immunoreactivity in benign and malignant epithelium. It was observed that the number of stained cells were significantly higher in tumour than in normal prostate tissues. It was also observed that AR positive cells are heterogeneously distributed within the tumour. Similar findings were reported in many previous studies by Qiu YQ et al[10], Sadi MV et al[28] and Takeda $\mathrm{H}$ et al. [11] AR expression was found to have a significant negative correlation with Gleason score and percentage of involved cores. No significant association was found with age, serum PSA level \& perineural invasion. A moderate, negative monotonic, significant correlation $\left(\mathrm{r}_{\mathrm{s}}=\right.$ $0.400, p=0.001$ ) was obtained between Androgen Receptor expression and Gleason score. It means that when Gleason Score increases, AR expression decreases i.e. well- differentiated tumours were associated with a high percentage of stained cells, as well as a high staining intensity, compared with moderately and poorly differentiated tumours. Results were similar to studies conducted by Theodoropoulos et al,[29] Takeda et al[11] Segawa et al[30] and Miyamoto KK et al. [12] But according to studies by Inoue et al[31] Li et al[32] \& Henshall et al,[33] high AR expression is associated with high Gleason score. This variation in study results may be due to heterogeneous expression of AR in carcinoma prostate, difference in the antibodies used to detect AR receptor in various studies and difference in quantitation of $A R$ immune reactivity in different studies.

A weak, negative monotonic, significant correlation $\left(\mathrm{r}_{\mathrm{s}}=-0.326, \mathrm{p}=0.009\right.$ was obtained between Androgen Receptor expression and percentage of involved cores. Literature review did not reveal any similar studies. There was no significant association between AR expression and clinical parameters such as age, serum PSA level. This was similar to studies conducted by Yi Qing Qiu et al [10] and Husain I et al. [14] Perineural invasion also showed no significant correlation. Literature review did not reveal any similar studies. Because of the difference in results of various studies and the heterogeneous expression of AR in carcinoma prostate, we need to find a standard AR immunoreactivity counting system that is reliable and reproducible before AR immunostaining can become a valuable molecular marker of carcinoma prostate.

\section{CONCLUSIONS}

The study focused on evaluating the relationship of Androgen Receptor expression with various prognostic factors associated with carcinoma prostate. It was found that AR expression has a significant negative correlation with Gleason score and percentage of involved cores. But other prognostic factors did not show significant correlation. Further studies with higher sample size and correlation with survival analysis are indicated in this regard. Such studies may throw more light on to this grey zone i.e., the role of AR expression as a predictive factor in the clinical course of carcinoma prostate.

\section{REFERENCES}

[1] IARC, 2012. http://gco.iarc.fr/today/fact-sheetscancers? cancer $=19 \&$ type $=0 \&$ sex $=1$.

[2] Moch H, Humphrey PA, Ulbright TM. WHO classification of tumours of the urinary system and male genital organs. $4^{\text {th }}$ edn. Lyon: IARC Press 2016.

[3] Ross JS, Jennings TA, Nazeer T, et al. Prognostic factors in prostate cancer. Pathology Patterns Reviews 2003;120(Suppl 1):S85-S100.

[4] Bostwick DG, Grignon DJ, Hammond ME, et al. Prognostic factors in prostate cancer. College of American Pathologists Consensus Statement 1999. Archives of Pathology \& Laboratory Medicine 2000;124(7):9951000. 
[5] Christiano AP, Yoshida BA, Dubauskas ZBA, et al. Development of markers of prostate cancer metastasis. Review \& perspective. Urologic Oncology: Seminars and Original Investigations 2000;5(5):217-23.

[6] Alers JC, Rochat J, Krijtenburg PJ, et al. Identification of genetic markers for prostatic cancer progression. Laboratory Investigation: A Journal of Technical Methods and Pathology 2000;80(6):931-42.

[7] Huggins C, Stevens RE, Hodges CV. Studies on prostatic cancer: II. The effects of castration on advanced carcinoma of the prostate gland. Archives of Surgery 1941;43(2):209-23.

[8] Ding Y, Yuan HQ, Kong F, et al. Ectopic expression of neurotrophic peptide derived from saposin $\mathrm{C}$ increases proliferation and upregulates Androgen Receptor expression and transcriptional activity in human prostate cancer cells. Asian Journal of Andrology 2007;9(5):601-9.

[9] Altuwaijri S, Wu CC, Niu YJ, et al. Expression of human AR cDNA driven by its own promoter results in mild promotion, but not suppression, of growth in human prostate cancer PC-3 cells. Asian Journal of Andrology 2007;9(2):181-8.

[10] Qiu YQ, Leuschner I, Braun PM. Androgen Receptor expression in clinically localized prostate cancer: immunohistochemistry study and literature review. Asian Journal of Andrology 2008;10(6):855-63.

[11] Takeda H, Akakura K, Masai M, et al. Androgen Receptor content of prostate carcinoma cells estimated by immunohistochemistry is related to prognosis of patients with stage D2 prostate carcinoma. Cancer 1996;77(5):934-40.

[12] Miyamoto KK, McSherry SA, Dent GA, et al. Immunohistochemistry of the Androgen Receptor in human benign and malignant prostate tissue. The Journal of Urology 1993;149(5):1015-9.

[13] De Winter JA, Trapman J, Brinkmann AO, et al. Androgen Receptor heterogeneity in human prostatic carcinomas visualized by immunohistochemistry. The Journal of Pathology 1990;160(4):329-32.

[14] Niroomand H, Nowroozi M, Ayati M, et al. Relationship between perineural invasion in prostate needle biopsy specimens and pathologic staging after radical prostatectomy. Nephrourology Monthly 2016;8(3):e36022.

[15] Tyagi B, Manoharan N, Raina V. A case control study on prostate cancer in Delhi. Asian Pacific Journal of Cancer Prevention 2010;11(2):397-401.

[16] Tindall EA, Monare LR, Petersen DC, et al. Clinical presentation of prostate cancer in black South Africans. The Prostate 2014;74(8):880-91.

[17] Spalding AC, Daignault S, Sandler HM, et al. Percent positive biopsy cores as a prognostic factor for prostate cancer treated with external beam radiation. Urology 2007;69(5)936-40.

[18] Freedland SJ, Aronson WJ, Terris MK, et al. The percentage of prostate needle biopsy cores with carcinoma from the more involved side of the biopsy as a predictor of prostate specific antigen recurrence after radical prostatectomy: results from the Shared Equal Access Regional Cancer Hospital (SEARCH) database. Cancer 2003;98(11):2344-50.
[19] Wong WW, Schild SE, Vora SA, et al. Association of percent positive prostate biopsies and perineural invasion with biochemical outcome after external beam radiotherapy for localized prostate cancer. International Journal of Radiation Oncology, Biology, Physics, 2004;60(1):24-9.

[20] Vargas SO, Jiroutek M, Welch WR, et al. Perineural invasion in prostate needle biopsy specimens. Correlation with extraprostatic extension at resection. American Journal of Clinical Pathology 1999;111(2):2238.

[21] De la Taille A, Antiphon P, Salomon L, et al. Prospective evaluation of a 21-sample needle biopsy procedure designed to improve the prostate cancer detection rate. Urology 2003;61(6):1181-6.

[22] D'Amico AV, Wu Y, Chen MH, et al. Perineural invasion as a predictor of biochemical outcome following radical prostatectomy for select men with clinically localized prostate cancer. The Journal of Urology 2001;165(1):126-9.

[23] Husain I, Shukla S, Soni P, et al. Role of Androgen Receptor in prostatic neoplasia versus hyperplasia. Journal of Cancer Research and Therapeutics 2016;12(1):112-6.

[24] Humphrey PA. Gleason grading and prognostic factors in carcinoma of the prostate. Modern pathology: an Official Journal of the United States and Canadian Academy of Pathology, Inc., 2004;17(3):292-306.

[25] Mazzucchelli R, Lopez-Beltran A, Cheng L, et al. Rare and unusual histological variants of prostatic carcinoma: clinical significance. BJU International 2008;102(10):1369-74.

[26] Randolph TL, Amin MB, Ro JY, et al. Histologic variants of adenocarcinoma and other carcinomas of prostate: pathologic criteria and clinical significance. Modern pathology: an Official Journal of The United States and Canadian Academy of Pathology, Inc., 1997;10(6):61229.

[27] Grignon DJ. Unusual subtypes of prostate cancer. Modern Pathology 2004;17(3):316-27.

[28] Sadi MV, Walsh PC, Barrack ER. Immunohistochemical study of androgen receptors in metastatic prostate cancer. Comparison of receptor content and response to hormonal therapy. Cancer 1991;67(12):3057-64.

[29] Theodoropoulos VE, Tsigka A, Mihalopoulou A, et al. Evaluation of neuroendocrine staining and Androgen Receptor expression in incidental prostatic adenocarcinoma: prognostic implications. Urology 2005;66(4):897-902.

[30] Segawa N, Mori I, Utsunomiya H, et al. Prognostic significance of neuroendocrine differentiation, proliferation activity and Androgen Receptor expression in prostate cancer. Pathology International 2001;51(6):452-9.

[31] Inoue T, Segawa T, Shiraishi T, et al. Androgen receptor, Ki67, and p53 expression in radical prostatectomy specimens predict treatment failure in Japanese population. Urology 2005;66(2):332-7. 
[32] Li R, Wheeler T, Dai $\mathrm{H}$, et al. High level of Androgen Receptor is associated with aggressive clinicopathologic features and decreased biochemical recurrence-free survival in prostate: cancer patients treated with radical prostatectomy. The American Journal of Surgical Pathology 2004;28(7):928-34.
[33] Henshall SM, Quinn DI, Lee CS, et al. Altered expression of Androgen Receptor in the malignant epithelium and adjacent stroma is associated with early relapse in prostate cancer. Cancer Research 2001;61(2):423-7. 